\title{
온열요법이 면역활성의 변화에 미치는 효과 Effects of the Heat Therapy on Changes of Immune Activities in Human Body
}

이상빈
남서울대학교 물리치료학과
Sang-Bin Lee(shinebin@naver.com)

\section{요약}

본 연구는 온열요법, 그 중 습열(moist heat)과 건열(dry heat)의 적용이 면역 활성의 변동에 미치는 효과를 알아보기 위한 것이다. 건강에 이상이 없는 연령 23 32세, 신장 $171.0 \pm 1.2 \mathrm{~cm}$, 체중 $68.0 \pm 2.2 \mathrm{~kg}$ 의 남성 15 명과 연령 $22 \sim 24$ 세, 신장 $159.5 \pm 1.2 \mathrm{~cm}$, 체중 $54.6 \pm 2.4 \mathrm{~kg}$ 의 여성 15 명을 대상으로 인체에 온열침수 (핫팩(KRS 12P, Karis Co., Korea))와 적외선 (발광 적외선등(Infrared, Ilshin Co., Korea))을 적용하여 보체와 같은 면역-활성 물질의 추이를 살펴보았다. 연구의 결과로써, 온열침수와 적외선을 적용한 결과 온열침수와 적외선 적용으로 보체 성분의 변동은 온열침수 적용으로 $\mathrm{Clq}$ 의 유의한 감소와 $\mathrm{C} 3$ (여성의 경 우) 및 $\mathrm{C} 4$ 의 감소가 나타남을 확인할 수 있었다. 그러나 적외선의 경우 $\mathrm{Clq}$ 와 $\mathrm{C} 3$ 및 $\mathrm{C} 4$ 의 증감에 별다른 영향을 미치지 못하였다. 이러한 연구의 결과로 미루어 온열침수의 적용으로 보체계의 활성을 확인할 수 있었으며 이러한 면역-활성의 증가는 선택적 경로(alternative pathway)가 아닌 고전적 경로(classical pathway)를 통해 이루어짐을 추정할 수 있었다. 따라서 본 연구의 결과는 극히 부분적 결과를 나타내지만, 온열침수와 적외선 적용으로 면역-증강효과가 다소 존재하는 것으로 사료된다.

- 중심어 : | 온열침수욕 | 적외선 | 보체계 | 면역활성 |

\section{Abstract}

The purpose of this study was to demonstrate immune-activities by heat therapy. To exam, furthermore, the immune effect is investigated from the healthy volunteer(male:15, female:15) by monitoring changes of immune substances such as $\operatorname{complements}(C 1 q, C 3$, and $C 4)$, a comparative study with warm water immersion $\left(40.8 \pm 0.3^{\circ} \mathrm{C}\right)$ and infrared $(250 \mathrm{~W})$ was carried out. The plasma analysis showed that the percentage of $\mathrm{C} 1 \mathrm{q}, \mathrm{C} 3$, and $\mathrm{C} 4$ was decreased in warm water immersion-stimulated group, but not in infrared-applied group, compared with control group from healthy volunteer. Therefore, these results suggest that the thermo-stimulation improved immune activity and inhibited complement-related inflammation through the warm water immersion-dependent classical pathway.

- keyword : | Warm Water Immersion | Infrared | Complement System | Immune-activities |

\footnotetext{
* 본 연구는 남서울대학교 연구과제로 수행되었습니다.
}

접수번호 : \#081009-005

접수일자 : 2008년 10월 09일
심사완료일 : 2009년 10월 23일

교신저자 : 이상빈, e-mail : shinebin@naver.com 


\section{I. 서 론}

인체를 비롯한 모든 동물은 박테리아 및 바이러스를 비롯한 각종 병원체와 미생물들의 침입에 노출되어 있 으며 이로 인한 질병의 발생으로 고통을 받고 있다. 이 러한 환경에서 생존하기 위해, 인체에는 세포벽과 같이 단순한 물리적 차단에 의한 비특이적 방법에서부터 면 역반응과 같은 특이적 기구를 통한 생체방어기전이 갖 추어져 있다[1]. 특히 면역계의 역할은 박테리아나 바이 러스와 같이 생체 내에 침입하는 물질들을 방어하고 생 체 내에서 일어나는 각종 이상 현상들을 제거하여 생체 의 항상성을 유지시키는 것으로서 항체, 보체, 세포간 매개자(mediator) 등의 체액성요소와 림파구, 대식세포 등의 세포성요소, 그리고 체액성요소와 세포성요소를 연결하는 수용체 그룹(receptor group) 등으로 구성되 어 있으며[2], 이물질을 인식하는 방법의 차이에 따라 선천성 면역계(innate immunity)와 후천성 면역계 (adaptive immunity)로 구분된다. 한편 선천성 면역계 의 한 부분인 보체(complement)는 혈장 중에 비활성 상태로 존재하는 단백질로서, $\mathrm{C1}-\mathrm{C} 9$ 까지의 9 개의 보체 성분을 포함, 조절자 등 약 20여 종의 성분으로 구성되 어 있으며 항체의 세균 옵소닌화(opsonization) 기능을 강화시켜 항체들에 의한 일부 세균의 살해를 가능하게 한다. 이러한 보체계(complement system)는 외부로부 터 감염된 병원체에 대하여 항원의존적 또는 비의존적 으로 이물질을 인식하여 이물질 표면상에 보체성분의 연쇄적인 한정분해와 분자집합반응을 하여 표적세포의 손상, 식작용효과 등을 통해 이물질을 제거하는 동적인 생체방어체계라고 할 수 있다[1].

한편, 인체의 생리적 작용을 개선시키고 항상성을 유 지하기 위해 흔히 이용되는 온열요법은 주로 물리치료 분야에서 적외선 등의 광선치료, 온습포(hot pack) 및 고온침수욕 등의 수치료, 고주파 및 초음파 등의 전기 치료분야에서 이용되고 있다[3]. 이 중, 온열침수욕은 순환의 촉진, 국소신진대사의 촉진, 통증 및 근경련의 감소 등의 생리적 효과를 위하여 이용되는데 온열침수 욕을 인체에 적용하면 모세혈관, 대동맥, 대정맥 등이 확장되어 혈류량이 증가되고 내장 혈관은 반사적으로
수축되며 말초혈관의 저항이 감소하여 혈류속도를 증 가시킨다. 또한 온열침수욕이 인체에 미치는 영향에 대 하여 민경옥(1993)은 체온조절을 위해 발한작용이 증가 되며, 환기량이 증가되는 등의 작용으로 심박수가 증가 한다고 하였으며[4] 윤선영 등(1994)은 심박수의 상승, 총 발한량의 증가, 땀 속의 $\mathrm{Cl}^{-}$이온의 감소를 보고한 바 있다[5].

온열의 생리적 효과를 위해 흔히 임상에서 사용되는 적외선은 물체에 흡수되면 열작용을 일으키기 때문에 열선이라고도 하는데, 사용이 간편하여 일반적으로 온 열요법에 쉽게 활용되고 있으며 열발생, 홍반형성, 색소 침착, 혈관의 확장과 충혈발생에 의한 진통작용 및 근 경련의 감소, 염증의 감소 등의 생리적 효과를 갖고 있 다[6]. 이와 같이, 온열침수욕과 적외선을 포함하여 온 열이 인체에 미치는 효과는 매우 다양하다. 최근에는 암세포의 치료효과를 높이기 위해 온열요법을 적용하 는 등 온열의 생리적 효과를 이용한 연구가 활발하게 이루어지고 있다. 그러나 인체의 최전방에서 질병의 발 생을 차단하고 있는 면역계의 활성에 대한 연구는 잘 이루어지지 않고 있으며 그 중에서도 온열침수욕과 적 외선이 인체의 면역 활성에 미치는 영향에 대한 연구는 매우 미비하다. 특히 보체계의 활성에 대해서는 각종 식품재료, 생약재 등 천연물질들이 보체계의 활성을 촉 진하여, 생체의 면역 부전상태를 개선하는 면역요법제 로 개발되고 있다는 연구는 많이 보고되어 있으나 온열 의 적용에 따른 보체계의 활성변화에 대한 연구는 전무 한 실정이다. 따라서 본 연구에서는 일상생활에서 흔히 활용할 수 있는 온열요법 중 온열침수욕과 적외선을 인 체에 적용하여 면역반응물질의 활성-변동을 관찰 및 분석함으로서 온열요법이 면역계에 미치는 영향을 추 정하고자 한다.

\section{II. 이론적 배경}

\section{1. 보체계의 활성변동에 대한 기전의 이해}

혈청 내에 존재하는 보체계(complement system)는 효소 단백질과 그 단백질의 억제제로 구성된 약 20여종 
의 혈액순환 단백질로써 항체의 작용을 보조함으로써 나타나는 용균반응과 “옵소닌화(opsonization)" 등의 반응을 유도하는 인자이다[7][8]. 이러한 보체계는 항원 -항체 복합체에 반응하지만 그 결합물-항원의 종류와 는 상관이 없는, 항원특이성을 가지고 있지 않다. 보체 계의 활성화가 증가 및 진행될수록 그 양은 감소하는 것이 일반적으로 알려져 있다[7][9]. 또한 보체계의 활 성화에는 항원-항체 ( $I g M$ 혹은 $I g G)$ 복합체 [antigen-antibody complex, $A g-A b$ complex] 의존적 $\mathrm{Cl}$ 의 활성화로 시작되는 고전적 경로(classical pathway)와 $A g-A b$ 복합체 비의존적 C3을 중심으로 활 성화되는 선택적 경로(alternative pathway)가 존재하 는 것이 알려져 있다. 여기서 $\mathrm{Cl}$ 은 $\mathrm{Clq}$ 와 $\mathrm{Clr}$ 및 $\mathrm{Cls}$ 와 함께 $\mathrm{Ca}^{2+}$ 존재 하에서 거대분자 $\left(\mathrm{Clq}_{-}-\mathrm{Clr}-\mathrm{Cl}\right)$ 로 존 재한다. 또한 이 두 경로는 C3까지 활성화되는 경로가 차이를 보이나 이후의 하위단계의 효소활성 경로는 동 일한 과정을 거치게 된다[8][10][그림 1].

여기서 고전적 경로는 활성화된 $\mathrm{C} 1$ 이 $\mathrm{C} 4$ 와 $\mathrm{C} 2$ 를 각 각 $\mathrm{C} 4 \mathrm{a}$ 와 $\mathrm{C} 4 \mathrm{~b}, \mathrm{C} 2 \mathrm{a}$ 와 $\mathrm{C} 2 \mathrm{~b}$ 로 분해한다. 이러한 분해과 정은 "일련의 과정(cascade)"으로써 하위 단계로 이행 되어 $\mathrm{C} 4 \mathrm{~b}$ 와 $\mathrm{C} 2 \mathrm{a}$ 가 결합하여(C4b.C2a) $\mathrm{C} 3$ 에 특이적으 로 작용하므로 C3 전환효소(C3 convertase)라 불리우 는 새로운 효소가 된다. 이렇게 생성된 C3 전환효소는 $\mathrm{C} 3$ 를 $\mathrm{C} 3 \mathrm{a}$ 와 $\mathrm{C} 3 \mathrm{~b}$ 로 분해한다. 또한 $\mathrm{C} 3 \mathrm{~b}$ 는 $\mathrm{C} 3$ 전환효소 와 결합하여 C5 전환효소(C5 convertase)를 형성하여 $\mathrm{C} 5$ 를 $\mathrm{C} 5 \mathrm{a}$ 와 $\mathrm{C} 5 \mathrm{~b}$ 로 분해한다. 이어서 $\mathrm{C} 5 \mathrm{~b}$ 는 $\mathrm{C} 6$ 과 $\mathrm{C} 7$ 및 $\mathrm{C} 8$ 과 각각 결합하여 $\mathrm{C} 5 \mathrm{~b}, 6,7,8$ 을 형성하게 된다. 이 렇게 형성된 C5b,6,7,8은 C9의 중합(polymerization)을 촉매함으로써 세포막 파괴의 특성을 지닌 "막침습복합 체(membrane attack complex, MAC)"를 형성하여 보 체의 활성을 나타낸다. 반면, 선택적 경로의 활성화는 $\mathrm{Ag}-\mathrm{Ab}$ 복합체가 아닌 미생물의 표면(microbial surfaces)과 지모산(zymosan)과 같은 복합 다당체 (complex polysaccharides)에 의해 경로의 활성화가 촉 발된다[8]. 여기서 $\mathrm{C} 3$ 는 자연적으로 분절되는(cleaved) 특성을 나타내어 $\mathrm{C} 3 \mathrm{~b}$ 의 형태를 취하게 되며, 분절된 $\mathrm{C} 3 \mathrm{~b}$ 는 factor $\mathrm{B}$ 와 복합체(C3b.B)를 이루고 factor $\mathrm{D}$ 에 의해서 분해된다 $(\mathrm{C} 3 \mathrm{~b} . \mathrm{Bb}+\mathrm{Ba})$. 이러한 $\mathrm{C} 3$ 전환효소는 properdin에 의해 안정화되는 특성을 가지게 되며 $\mathrm{C} 3$ 를 $\mathrm{C} 3 \mathrm{a}$ 와 $\mathrm{C} 3 \mathrm{~b}$ 로 분해한다. 이어서 분해 된 $\mathrm{C} 3 \mathrm{~b}$ 는 $\mathrm{C} 3$ 전환 효소와 결합하여 $\mathrm{C} 5$ 전환효소를 형성함으로써 $\mathrm{C} 5$ 를 $\mathrm{C} 5 \mathrm{a}$ 와 $\mathrm{C} 5 \mathrm{~b}$ 로 분해하여 일련의 과정을 거쳐 $\mathrm{MAC}$ 를 형 성하여 활성을 나타낸다[10][그림 1].

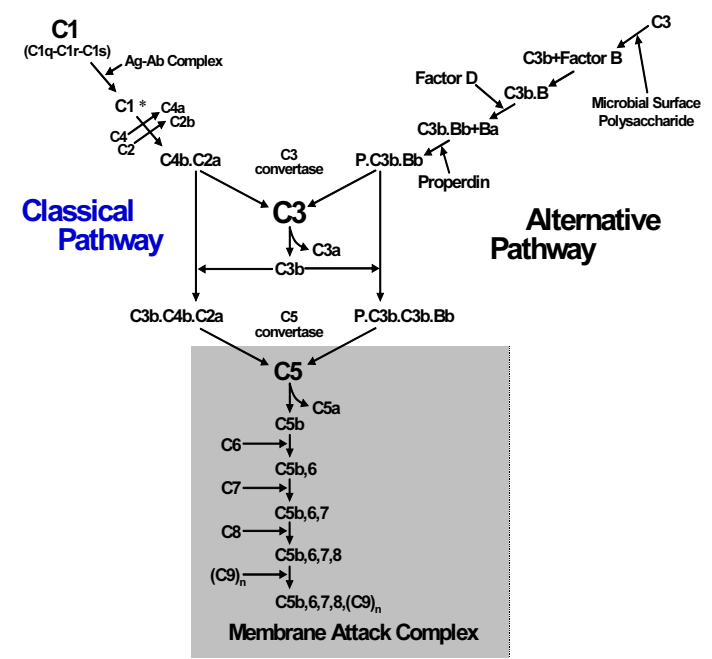

그림 1. 보체계(complement system)의 도해

\section{III. 연구 방법}

\section{1. 연구대상 및 환경}

본 연구에 참여한 대상자는 건강에 이상이 없는 연령 23 32세, 신장 $171.0 \pm 1.2 \mathrm{~cm}$, 체중 $68.0 \pm 2.2 \mathrm{~kg}$ 의 남성 15 명과 연령 22 24세, 신장 $159.5 \pm 1.2 \mathrm{~cm}$, 체중 $54.6 \pm 2.4 \mathrm{~kg}$ 의 여성 15 명을 각각 무작위로 선발하여 연구를 진행하 였다. 신장과 체중의 측정은 체중계와 신장측정 장치가 함께 내장되어 있는 신장 및 체중 측정기 $\left(\mathrm{JENIX}^{\mathrm{R}}\right.$ DS-102, Dongsan Co., Korea)를 사용하여 2회 측정한 후 평균을 산출하였다. 연구환경은 $23 \pm 1^{\circ} \mathrm{C}$ 의 온도를 유 지하였다. 모든 연구조작은 바로 선 자세를 유지한 상 태에서 측정하였다.

또한 본 측정연구에 들어가기에 앞서 피 연구자의 생 리기간을 피하였으며, 일절 실험내용에 대한 언급을 하 지 않은 상태에서 일정시간(14:00 16:00)에 혈액을 채 
집 및 채취하였다. 생체기전(In Vivo)의 오차를 줄이고 자 24시간의 합숙통제와 함께 동일한 제한식이와 음료 를 제공하였다. 음주와 투약을 금지하도록 하였으며, 기 준선이 기록된 음료용 컵을 제공하여 음수한 컵의 수를 정(正)자로 표시하도록 하였다.

\section{2. 온열침수와 적외선 적용}

본 연구는 습열(wet heat)의 형태로 인체에 적용하는 온열침수욕과 건열(dry heat)의 형태를 나타내는 적외 선을 인체의 양쪽 족부에 적용하였다.

본 연구에서 적용한 온열침수방법은 자동온도조절 $\left(0^{\circ} \mathrm{C} \sim 100^{\circ} \mathrm{C}\right)$ 이 가능한 핫팩통 $(\mathrm{KRS} 12 \mathrm{P}$, Karis Co., Korea)에 물을 적정량 채운 후 $42^{\circ} \mathrm{C}$ 에 온도를 맞추어 자동조절을 세팅하였다. 적용 전, 후 수은온도계로 눈높 이에서 눈금을 확인하였다 $\left(40.8 \pm 0.3^{\circ} \mathrm{C}\right)$ [11][12]. 모든 자원자의 온열침수적용은 무를관절 $90^{\circ}$ 굴곡상태로 의 자의 높이를 맞추었으며, 등받이가 있는 의자를 제공해 줌으로써 상체의 무게가 분산될 수 있게 함으로써 체간 의 이완을 원활하게 하였다. 침수부위는 양 족부 경골 내과 상부 $1 / 3$ 범위 내에서 침수하도록 물의 높이를 조 절하였다. 침수시간은 총 2 회 적용하였으며 적용시간은 인체에 온열적용에 의한 생리적 효과가 나타나는 시간 인 30분[4]씩 각 회마다 적용하였다(총 60분).

본 연구에 사용한 적외선은 출력 $250 \mathrm{~W}$ 의 발광 적외 선등(Infrared, Ilshin Co., Korea)을 사용하였다. 조사부 위는 양 족배부로써 조사부위와 $90^{\circ}$ 를 이룬 각도의 약 $20 \sim 25 \mathrm{~cm}$ 높이에서 2 대의 적외선등을 각 조사부위에 적용하였다. 적외선 조사시간은 총 2 회를 실시하였으며 각각 30 분(총 60 분)을 적용하였다. 모든 피연구자의 적 외선 조사 시 자세는 무릎관절을 완전 신전시킨 자세로 앉은 자세를 취하게 하도록 유지시킨 후 양팔로 상체를 지탱하도록 하였다. 인체 연구의 환경은 $23 \pm 1^{\circ} \mathrm{C}$ 의 온도 를 유지하도록 하였으며, 상의는 반팔 $\mathrm{T}-$ 셔츠 1 장과 (여성의 경우 브래지어 착용) 하의는 속옷 1 장과 반바 지 1장으로 통일하였다.

\section{3. 혈액 채취 및 분석}

온열적용 유무 및 성별 비교에 따른 $\mathrm{Clq}, \mathrm{C} 3, \mathrm{C} 4$ 를
측정하기 위해 혈장과 혈청을 채취하였다. 혈액채취는 두 번째 실시한 온열적용을 마친 직후 적용 자세를 유 지하도록 하여 좌, 우 주와정맥(cubital vein)에서 약 8 10m $\ell$ 의 혈액을 취하였다. 특히 각 측정물질의 반감 기를 고려하여 두 번째 실시한 온열적용을 마친 직후 $1 \sim 2$ 분 이내에 혈액을 채취하였으며, 일중변동의 오차 를 줄이기 위해 일정시간(14:00 16:00)에 취하였다

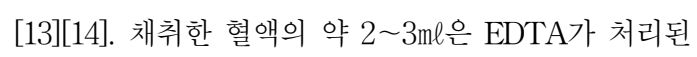
전용 튜브에 넣어 냉장보관 하였으며, 동시에 약 7 8 $\mathrm{ml}$ 의 혈액은 유리튜브에 넣어 실온에서 30 60분 방치 한 후 원심분리기를 사용하여 10 분간 $3,000 \mathrm{rpm}$ 으로 혈 청을 분리하였다. 분리한 혈청은 혈청분리관으로 옮겨 측정 시까지 냉동보관 하였다.

$\mathrm{C} 3$ 와 $\mathrm{C} 4$ 의 측정은 네페로메트리(nepherometry)로 분석하였다. $\mathrm{Clq}$ 의 측정은 면역확산법(single radial immunodiffusion, SRID)으로 분석하였다(Greencross Laboratory, 경기도 용인시 소재).

\section{4. 통계학적 분석}

본 연구의 통계처리는 각 연구결과에 따라 SAS 소프 트웨어(version 6.12)를 사용하여 평균과 표준편차를 산출하였다. 또한 각 비교군 사이의 통계적 유의성을 검정하기 위한 유의수준은 $a=.05$ 로 설정하여 $t$-검정과 일원분산분석(one-way ANOVA)을 실시하였다. 연구 성적은 mean $\pm \mathrm{SEM}$ 으로 나타내었다.

\section{IV. 연구 결과}

\section{1. 온열적용 유무와 성별에 따른 보체(C1q, C3, C4) 활성의 변동}

온열적용의 유무 및 성별에 따른 보체계(complement system)의 일부 단백질 즉, $\mathrm{Clq}$ 와 $\mathrm{C} 3, \mathrm{C} 4$ 의 수치 변동 은 다음과 같았다.

온열적용 유무에 따른 $\mathrm{Clq}$ 변동의 경우, 남성과 여성 모두에서 온열을 적용하지 않은 대조군(남성; $11.2 \pm 0.5$ $\mathrm{mg} / \mathrm{d} \ell$, 여성; $10.3 \pm 0.3 \mathrm{mg} / \mathrm{d} \ell$ )에 비해 온열침수(남성; $9.6 \pm 0.2 \mathrm{mg} / \mathrm{dl}$, 여성; $9.5 \pm 0.3 \mathrm{mg} / \mathrm{d \ell})$ 를 적용한 실험군에 
서 $\mathrm{Clq}$ 의 수치가 유의한 수준으로 감소함을 확인할 수 있었다. 그러나 적외선 조사군(남성; $11.7 \pm 0.5 \mathrm{mg} / \mathrm{d} \ell$, 여 성; $11.1 \pm 0.5 \mathrm{mg} / \mathrm{d} \ell)$ 의 경우 별다른 차이가 없거나 오히 려 증가하는 양상을 나타냈다[그림 2A][그림 2B]. 또한 남성과 여성의 구별 없이 온열적용 유무에 대한 결과분 석 역시 대조군 $(10.7 \pm 0.3 \mathrm{mg} / \mathrm{dl})$ 에 비해 온열침수 $(9.6 \pm 0.2 \mathrm{mg} / \mathrm{d} \ell)$ 의 적용군에서 유의한 수준의 감소가 나 타남을 확인할 수 있었다. 그러나 적외선의 경우는 대 조군에 비해 연구군 $(11.4 \pm 0.3 \mathrm{mg} / \mathrm{d \ell})$ 에서 증가하는 양상 을 나타냈다[그림 2C][표 1].

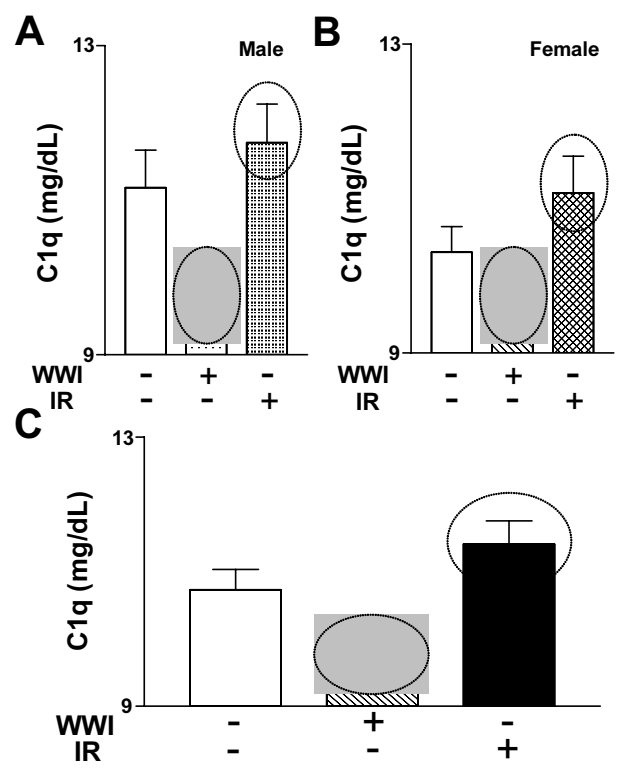

그림 2. 인체의 $\mathrm{C} 1 \mathrm{q}$ 에 대한 침수욕 및 적외선의 효과

표 1. 인체의 $\mathrm{C} 1 \mathrm{q}$ 에 대한 침수욕 및 적외선의 효과

\begin{tabular}{|c|c|c|c|}
\hline & 대조군 & 온열침수군 & 적외선군 \\
\hline $\mathrm{C} 1 \mathrm{q}$ & $10.7 \pm 0.3 \mathrm{mg} / \mathrm{dl}$ & $9.6 \pm 0.2 \mathrm{mg} / \mathrm{dl}$ & $11.4 \pm 0.3 \mathrm{mg} / \mathrm{dl}$ \\
\hline
\end{tabular}

온열적용 유무에 따른 C3 변동의 경우, 남성에서 온 열을 적용하지 않은 대조군 $(92.5 \pm 4.2 \mathrm{mg} / \mathrm{d \ell})$ 에 비해 온 열침수 $(94.9 \pm 4.2 \mathrm{mg} / \mathrm{d} \ell)$ 와 적외선 조사군 $(97.7 \pm 4.3 \mathrm{mg} /$ $\mathrm{d} \ell$ )에서 별다른 차이가 없거나 증가의 양상이 나타남을 확인할 수 있었다[그림 3A]. 여성에서는 대조군 $(92.1 \pm 3.0 \mathrm{mg} / \mathrm{d} \ell)$ 에 비해 온열침수 $(91.1 \pm 3.6 \mathrm{mg} / \mathrm{d} \ell)$ 적용
군에서 감소의 경향을 나타낸 반면, 적외선 $(96.3 \pm 3.9 \mathrm{mg}$ (de) 조사군에서는 증가의 경향을 나타냈다[그림 $3 \mathrm{~B}]$. 그러나 남성과 여성의 구별 없이 온열적용 유무에 대한 결과분석은 대조군 $(92.3 \pm 2.5 \mathrm{mg} / \mathrm{d \ell})$ 에 비해 온열침수 $(93.0 \pm 2.8 \mathrm{mg} / \mathrm{d} \ell)$ 와 적외선 $(97.0 \pm 2.9 \mathrm{mg} / \mathrm{dl})$ 조사군 모두 에서 별다른 차이가 없거나 증가하는 경향을 나타냈다 [그림 3C][표 2].

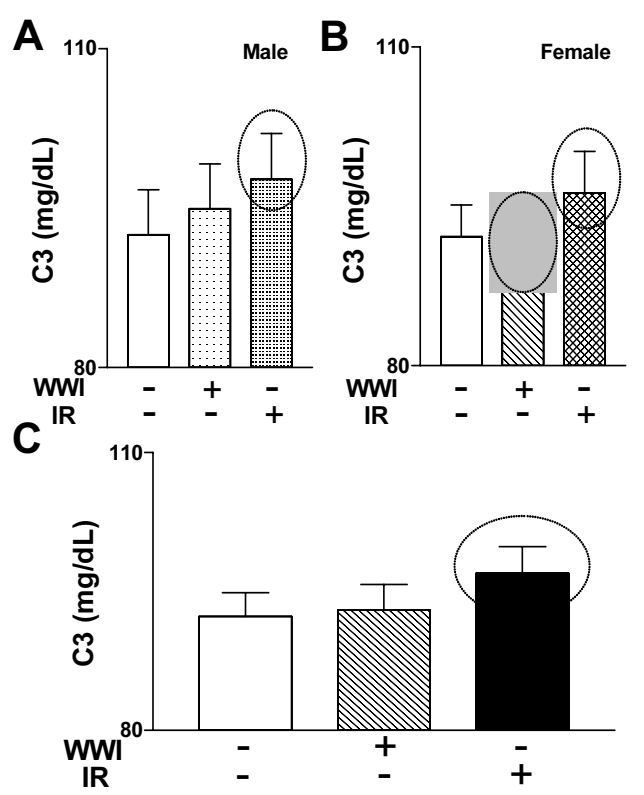

그림 3. 인체의 C3에 대한 침수욕 및 적외선의 효과

표 2. 인체의 $\mathrm{C} 3$ 에 대한 침수욕 및 적외선의 효과

\begin{tabular}{|c|c|c|c|}
\hline & 대조군 & 온열침수군 & 적외선군 \\
\hline C3 & $92.3 \pm 2.5 \mathrm{mg} / \mathrm{dl}$ & $93.0 \pm 2.8 \mathrm{mg} / \mathrm{dl}$ & $97.0 \pm 2.9 \mathrm{mg} / \mathrm{dl}$ \\
\hline
\end{tabular}

온열적용 유무에 따른 $\mathrm{C4}$ 변동의 경우, 남성에서 온 열을 적용하지 않은 대조군 $(18.7 \pm 1.3 \mathrm{mg} / \mathrm{d} \ell)$ 에 비해 온 열침수 $(19.0 \pm 1.4 \mathrm{mg} / \mathrm{d \ell})$ 와 적외선 조사군(19.5 $\pm 1.6 \mathrm{mg} /$ $\mathrm{d \ell})$ 에서 별다른 차이가 없거나 증가의 양상이 나타남을 확인할 수 있었다[그림 4A]. 여성에서는 대조군 $(17.1 \pm 1.6 \mathrm{mg} / \mathrm{d} \ell)$ 에 비해 온열침수 $(16.4 \pm 1.6 \mathrm{mg} / \mathrm{d} \ell)$ 적용 군에서 감소의 경향을 나타낸 반면, 적외선 $(16.9 \pm 1.7 \mathrm{mg}$ $/ \mathrm{d} \ell$ ) 조사군에서는 별다른 차이가 나타나지 않았다[그 
림 4B]. 그러나 남성과 여성의 구별 없이 온열적용 유무 에 대한 결과분석은 대조군 $(17.9 \pm 1.0 \mathrm{mg} / \mathrm{d \ell})$ 에 비해 온 열침수 $(17.7 \pm 1.1 \mathrm{mg} / \mathrm{d} \ell)$ 와 적외선 $(18.2 \pm 1.2 \mathrm{mg} / \mathrm{d} \mathrm{d})$ 조사 군 모두에서 별다른 차이가 없었다[그림 4C][표 3].

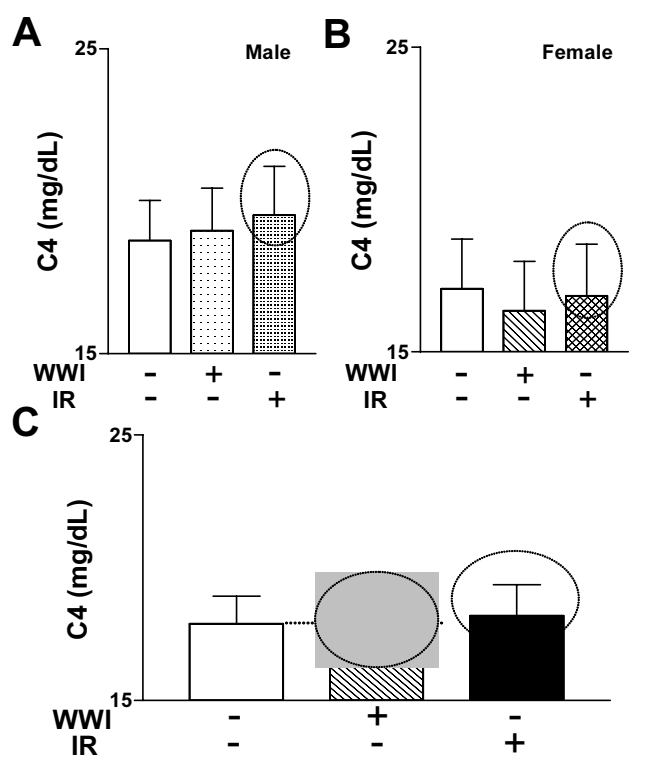

그림 4. 인체의 C4에 대한 침수욕 및 적외선의 효과

표 3. 인체의 $\mathrm{C} 4$ 에 대한 침수욕 및 적외선의 효과

\begin{tabular}{|l|c|c|c|}
\hline & 대조군 & 온열침수군 & 적외선군 \\
\hline $\mathrm{C} 4$ & $17.9 \pm 1.0 \mathrm{mg} / \mathrm{dl}$ & $17.7 \pm 1.1 \mathrm{mg} / \mathrm{dl}$ & $18.2 \pm 1.2 \mathrm{mg} / \mathrm{dl}$ \\
\hline
\end{tabular}

\section{V. 고 찰}

보체계는 고등생물에서 액성 면역계의 일부를 담당 하는 인자로서 항원침입 시 항체와 달리 비특이적으로 활성화되어 표적세포의 분해, 대식세포와 림프구의 활 성화, 화학주화(opsonization)를 통해 체내 병원체 등을 제거하는 주역할 이외에도 활성화과정 중 생성되는 보 체산물의 작용으로 인해 혈관투과성과 부종의 증가, 백 혈구 주화, 용해효소의 방출, 응집반응에 따른 혈소판 방출, 대식세포로부터 프로스타글란딘(prostaglandin) 생성 등의 특정 면역반응이 유도, 조절되어 염증, 알레
르기 반응과 같은 숙주면역반응에 중요한 역할을 담당 한다[15]. 이러한 체내 시스템의 역할로 인체는 건강을 유지할 수 있게 된다.

한편, 온열의 적용은 인체의 건강과 항상성의 유지를 위해 고대에서부터 이루어져 왔다. 온열자극에 의해 인 체에서 나타나는 생리학적 효과로는 축삭반사, 화학물 질의 방출 등으로 인한 순환의 촉진, 국소신진대사의 촉진, 온열이 적용된 부위의 혈관을 통한 백혈구의 이 동증가, 통증 및 근경련의 감소, 조직의 점탄성변화 등 이 있다. 이러한 체내 효과를 나타내기 위하여 여러 가 지 방법으로 온열을 인체에 적용하고 있으나 임상에서 는 온열침수욕과 적외선을 이용한 방법이 일반적으로 적용되고 있다.

온열침수욕을 적용하게 되면 모세혈관, 대동맥, 대정 맥 등이 확장되어 혈류량이 증가되고 내장 혈관은 반사 적으로 수축하며 말초혈관의 저항이 감소하여 혈류속 도를 증가시킨다. 이러한 온열침수욕의 효과로는 혈관 의 수축, 혈압의 상승, 심박수 및 혈류량 증가, 근 수축 력의 자극, 피부의 발적, 촉각기능저하 등이 있다[4]. 또 한, 일상생활에서 흔히 접할 수 있는 태양광선을 분석 해보면 자외선, 가시광선, 적외선으로 크게 3 가지로 나 뉘는데, 이 중 생리적 효과를 가지고 있는 것은 적외선 과 자외선이다. 적외선은 $760-1,500 \mathrm{~nm}$ 의 파장을 가지 고 있으며 여러 분야에 다양하게 이용되고 있다. 적외 선이 인체에 미치는 효과로는 혈류의 증가, 발한의 증 가와 노폐물 배설의 증가, 신진대사의 증가, 진통 등의 효과가 있다. 특히 적외선의 인체적용에 따라 백혈구가 증가되어 식균작용이 활발해져 소염효과가 증가한다는 것과 림프순환의 증가로 인하여 인체에 여러 가지 스트 레스로 인해 쌓이기 쉬운 노폐물의 배설을 촉진하는 효 과가 있다는 것은 널리 알려진 사실이다[6]. 이와 같이 온열의 효과는 일반적인 생리적 변화와 함께 여러 가지 세포의 변화를 일으켜 인체의 질병발생 억제능력 및 치 유능력에 적지 않은 영향을 미친다.

질병발생억제 및 치유에 관한 온열적용의 효과로서 Engin(1994)은 온열요법과 항암제치료를 병행한 결과 뇌종양, 난소종양, 유방암 등 악성종양의 치료에 효과가 있었다고 보고하였으며[16] 이상린(1997)은 $43^{\circ} \mathrm{C}$ 에서 
신세포암 세포주에 2 시간 및 4 시간 동안 온열을 적용한 결과, 4 시간 동안 고온처리한 세포주에서 성장억제율의 증가와 항암제 감수성의 증가를 보였다고 하였다[17]. 또한 Fajardo 등(1980)은 종양세포를 $44^{\circ} \mathrm{C}$ 로 30 분간 온 열요법을 가하여 세포막의 상당부분이 소실되었으며 약 6시간 후에는 핵의 위축이 관찰되었다고 하였고[18] 문창우(1999)는 적외선을 이용한 온열치료를 국소로 진 행된 직장암의 악성종양에 적용하여 생존율에 대한 분 석을 함으로서 적외선의 온열효과가 암치료에 미치는 영향에 대하여 발표하였다[19]. 본 연구에서는 종양세 포에 대한 연구결과는 아니지만 온열의 인체적용이 보 체계의 활성을 통한 면역활성에 영향을 미쳐 인체의 질 병발생억제에 효과가 있는 것으로 나타났다.

또한 본 연구에서는 온열적용에 따른 탐식 및 용균의 작용 등에 관여하는 보체계(complement system) 활성 의 변화와 함께 활성 경로 중 어느 경로와 연관성이 있 는지를 관찰하였다. 그 결과 온열침수 적용군의 남녀 모두에서 $\mathrm{Clq}$ 의 유의한 감소를 나타내었으며, 증감에 대한 성별의 차이는 있으나 $\mathrm{C} 3$ 와 $\mathrm{C} 4$ 가 온열침수 적용 군에서 감소의 경향이 나타났다. 이러한 결과로 미루어 온열침수의 적용은 보체계의 활성을 증가시켜 면역체 계의 활성화를 경유한 인체의 저항성 증진에 부분적으 로 기여함을 확인할 수 있었으며, 특히 고전적 경로 (classical pathway)를 통해 이루어짐을 추정할 수 있었 다. 그러나 본 인체연구의 결과 적외선 적용은 나타나 는 면역-활성 증가의 경로는 정확히 교대경로라고 확 인할 수는 없으나 고전적 경로는 경유하지 않는 것으로 추정할 수 있었다.

본 측정연구의 결과는 극히 부분적 내용에 해당되기 때문에 단정 짓기는 어려우나 본 연구 결과를 근거로 향후, 보다 체계적이고 심도 있는 연구측정 및 분석이 이루어 질 경우 온열요법의 발전에 보탬이 될 것으로 사료된다.

\section{VI. 결 론}

본 연구에서 온열침수(warm water immersion,
$W W I)$ 와 적외선(infrared)을 인체에 적용한 결과 보체 성분의 변동은 온열침수 적용으로 $\mathrm{Clq}$ 의 유의한 감소 와 $\mathrm{C} 3$ (여성) 및 $\mathrm{C} 4$ 의 감소가 나타남을 확인할 수 있었 다. 그러나 적외선의 경우 $\mathrm{Clq}$ 와 $\mathrm{C} 3$ 및 $\mathrm{C} 4$ 의 증감에 별 다른 영향을 미치지 못하였다. 또한 온열침수의 적용은 성별에 차이가 있으며 $\mathrm{Clq}$ 와 C3 및 $\mathrm{C} 4$ 의 감소를 가져 오는 것으로 미루어 고전적 경로를 통해 활성화됨을 유 추할 수 있었다. 따라서 온열침수와 적외선 적용 후, 여 러 가지 생리학적 효과로 인하여 나타난 면역활성 물질 의 변동은 그 결과가 부분적 내용을 지지함에도 불구하 고, 면역증강효과가 다소 존재하는 것으로 사료되며 이 에 따라 온열의 면역효과에 대한 더 많은 연구가 진행 되어야 할 것이다.

\section{참 고 문 헌}

[1] T. A. Bellanti, "The complement system. In Immunology III," Saunders, Philadelphia, p.106, 1985.

[2] E. Benzamini. and S. Leskowitz, "Complement," Immunology. Alan R. Liss, Newyork, p.121, 1988.

[3] 김순희, 김근조, 민경옥, 근골격계 및 순환계 질환 별물리치료, 하늘뜨락, pp.13-15, 2006.

[4] 민경옥, 온열 및 수치료, 대학서림, 1993.

[5] 윤선영, 최정화, "고온 침수욕이 인체의 체온조절 에 미치는 영향”, 한국인간온열환경학회지, 제 1 권, 제1호, p.20, 1994.

[6] 김순희, 문옥곤, 이준희, 광선치료학, 하늘뜨락, pp.141-158, 2008.

[7] I. M. Roitt, Essential immunology, 8th ed., Blackwell scientific publications, 1994.

[8] S. C. Makrides, "Therapeutic inhibition of the complement system," Pharmacol. Rev, Vol.50, No.1, pp.59-87, 1998.

[9] R. C. Cotran, V. Kumar, and T. Collins, Pathologic basis of disease. 6th ed, W.B. 
Saunders Co, 1999.

[10] M. K. Liszewski, T. C. Farries, D. M. Lublin, I. A, Rooney, and J. P. Atkinson, "Control of the complement system," Adv. Immunol, 61, pp.201-283, 1996.

[11] H. Kurabayashi, K. Tamura, J. Tamura, and K. Kubota, "The effects of hydraulic pressure on atrial natriuretic peptide during rehabilitative head-out water immersion," Life Sci, Vol.69, No.9, pp.1017-1021, 2001.

[12] O. Ahlers, B. Hildebrandt, A. Dieing, M. Deja, T. Bohnke, P. Wust, H. Riess, H. Gerlach, and T. Kerner, "Stress induced changes in lymphocyte subpopulations and associated cytokines during whole body hyperthermia of 41.8-42.2ㄷ," Eur. J. Appl. Physiol, Vol.95, No.4, pp.298-306, 2005.

[13] H. U. Lutz, P. Stammler, E. Jelezarova, M. Nater, and P. J. Spath, "High doses of immunoglobulin $G$ attenuate immune aggregate-mediated complement activation by enhancing physiologic cleavage of $\mathrm{C} 3 \mathrm{~b}$ in C3bn-IgG complexes," Blood, Vol.88, No.1, pp.184-193, 1996.

[14] M. K. Pangburn and N. Rawal, "Structure and function of complement C5 convertase enzymes," Biochem. Soc. Trans, 30(Pt 6), pp.1006-1010, 2002.

[15] T. G. Egwang, A. D. Befus,"The role of complement in the induction and regulation of immune responses," Immunology, 51, p.207, 1984.

[16] K. Engine, "Hyperthermia in cancer treatment," Neoplasm, Vol.41, No.5, 1994.

[17] 이상린, "온열요법이 신세포암 세포주의 항암제 감수성에 미치는 영향”, 인하대학교 대학원 석사 학위논문, p21, 1997.

[18] L. F. Fajardo, B. Egbert, J. Marmor, G. M.
Hahn, "Effects of hyperthermia in malignant tumor," Cancer, 45, pp.613-623, 1980.

[19] 문창우, 김영호, 정태식, 염하용, “국소 진행된 직 장암의 방사선-온열치료의 결과-생존율에 대한 분석”, 대한온열종양학회지, Vol.4, No.1, pp.55-66, 1999.

\section{저 자 소 개}

이 상 빈(Sang-Bin Lee) 정회원

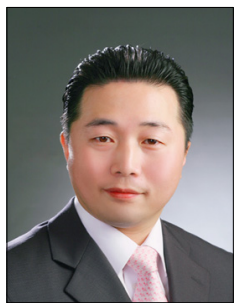

- 2001년 2월 : 용인대학교 물리치 료학과(물리치료학석사)

- 2007년 2월 : 용인대학교 물리치 료학과(물리치료학박사)

- 2007년 3월 현재 : 남서울대 학교 물리치료학과 전임강사

<관심분야> : 정형물리치료, 노인물리치료 